\title{
Spatial differences in gene expression in the bovine oviduct
}

\author{
Veronica Maillo ${ }^{1}$, Celia de Frutos ${ }^{1}$, Peadar O'Gaora ${ }^{2}$, Niamh Forde ${ }^{3}$, Gregory W Burns ${ }^{4}$, \\ Thomas E Spencer ${ }^{4}$, Alfonso Gutierrez-Adan ${ }^{1}$, Patrick Lonergan ${ }^{5}$ and Dimitrios Rizos ${ }^{1}$ \\ ${ }^{1}$ Departamento de Reproduccion Animal, Instituto Nacional de Investigacion y Tecnologia Agraria y Alimentaria \\ (INIA), Madrid, Spain, ${ }^{2}$ School of Biomolecular and Biomedical Sciences, University College Dublin, Belfield, \\ Dublin 4, Ireland, ${ }^{3}$ Division of Reproduction and Early Development, Leeds Institute of Cardiovascular and \\ Molecular Medicine, School of Medicine, University of Leeds, Clarendon Way, Leeds, UK, ${ }^{4}$ Division of Animal \\ Sciences and Department of Obstetrics, Gynecology and Women's Health, University of Missouri, Columbia, \\ Missouri, USA, and ${ }^{5}$ School of Agriculture and Food Science, University College Dublin, Belfield,
}

Dublin 4, Ireland

Correspondence should be addressed to D Rizos; Email: drizos@inia.es

\begin{abstract}
The aim of this study was to compare the transcriptome of the oviductal isthmus of pregnant heifers with that of cyclic heifers as well as to investigate spatial differences between the transcriptome of the isthmus and ampulla of the oviduct in pregnant heifers. After synchronizing crossbred beef heifers, those in standing oestrus (=Day 0 ) were randomly assigned to cyclic (non-bred, $n=6)$ or pregnant (artificially inseminated, $n=11$ ) groups. They were slaughtered on Day 3 and both oviducts from each animal were isolated and cut in half to separate ampulla and isthmus. Each portion was flushed to confirm the presence of an oocyte/embryo and was then opened longitudinally and scraped to obtain epithelial cells which were snap-frozen. Oocytes and embryos were located in the isthmus of the oviduct ipsilateral to the corpus luteum. Microarray analysis of oviductal cells revealed that proximity to the corpus luteum did not affect the transcriptome of the isthmus, irrespective of pregnancy status. However, 2287 genes were differentially expressed $(P<0.01)$ between the ampulla and isthmus of the oviduct ipsilateral to the corpus luteum in pregnant animals. Gene ontology revealed that the main biological processes overrepresented in the isthmus were synthesis of nitrogen, lipids, nucleotides, steroids and cholesterol as well as vesicle-mediated transport, cell cycle, apoptosis, endocytosis and exocytosis, whereas cell motion, motility and migration, DNA repair, calcium ion homeostasis, carbohydrate biosynthesis, and regulation of cilium movement and beat frequency were overrepresented in the ampulla. In conclusion, large differences in gene expression were observed between the isthmus and ampulla of pregnant animals at Day 3 after oestrus.

Reproduction (2016) 152 37-46
\end{abstract}

\section{Introduction}

The oviduct connects the ovary with the uterus. Its importance during early embryo development can be questioned due to the fact that embryos can be obtained in vitro in the absence of exposure to the oviduct. However, it has been clearly demonstrated that culture of in vitro produced bovine zygotes in the oviducts of cattle (Tesfaye et al. 2007, Gad et al. 2012), sheep (Enright et al. 2000, Lazzari et al. 2002, Rizos et al. 2002) or even mice (Rizos et al. 2007, 2010) improves embryo quality measured in terms of morphology, gene expression, cryotolerance and pregnancy rate after transfer. The importance of the oviduct resides in its ability to store and provide a suitable microenvironment to capacitate spermatozoa, to facilitate fertilization, and to support the early stages of embryo development, encompassing the critical checkpoint of embryonic genome activation.
Anatomically, the oviduct is divided in three different parts: the infundibulum, responsible for collecting the cumulus-oocyte complex (COC) at ovulation, the ampulla which transports the COC to the ampullaryisthmic junction where fertilization takes place, and the isthmus which is the region where early embryonic development occurs up to Day 3.5-4 (16-cell stage). Internally, the oviductal epithelium is made up of ciliary and secretory cells; the secretory cells are responsible for secreting and actively transporting the proteins, amino acids and ions that are present in the oviductal fluid (Hugentobler et al. 2007a, 2010).

The oviduct is a dynamic organ. Thus, during the oestrous cycle, modifications in the proportion of secretory and ciliary cells (Yániz et al. 2000), in the transcriptome of these cells (Bauersachs et al. 2003, 2004) and also in the composition of the oviductal fluid (Hugentobler et al. 2007b) have been reported. It has been shown that the proportion of ciliary and 
secretory cells changes depending on the phase of the oestrous cycle, the oviductal region and basal or apical areas within folds (Yániz et al. 2000). For example, in the ampulla, during the follicular phase, there are numerous ciliated cells, while during the luteal phase, the secretory cells predominate (Abe 1996, Areekijseree 2003). By contrast, the proportion of each cell type in the isthmus is relatively constant throughout the oestrous cycle (Abe 1996).

Temporal changes occur in the transcriptome of the oviduct epithelium during the oestrous cycle in cattle (Gabler et al. 1999, Lapointe \& Bilodeau 2003, Bauersachs et al. 2004, Swangchan-Uthai etal. 2011) and mice (Jeoung \& Bridges 2011), and the menstrual cycle in humans (Horne et al. 2008). Moreover, transcriptomic differences between the oviducts ipsilateral and contralateral to the corpus luteum (CL) have been described (Bauersachs et al. 2003). Recently, changes in the expression of mRNA within the epithelium of the ampulla and isthmus of cyclic heifers in the follicular (Day 8 after oestrus) or luteal (Day 11-12 after oestrus) phase were described (Cerny et al. 2015). However, the physiological relevance of studying such changes in the oviduct after Day 4 is questionable as the embryo has entered the uterus by this time.

Oviductal fluid (OF) is a complex mixture of constituents derived from plasma plus some specific proteins produced by the secretory cells (Leese 1988) responsible for nurturing the embryo during the early stages of development. The concentration of certain amino acids in the OF during the oestrous cycle is higher than that in plasma, suggesting that the oviduct epithelium is responsible for this synthesis or at least the active transport of these amino acids into the oviduct lumen (Hugentobler et al. 2007b).

We have previously described changes in the oviductal transcriptome in pregnant heifers following the transfer of multiple embryos (Maillo et al. 2015). There is a paucity of data on the spatial variation on gene expression within the oviduct. Therefore, the aim of this study was to compare the transcriptome of the oviductal isthmus of pregnant heifers with that of cyclic heifers as well as to investigate spatial differences between the transcriptome of the isthmus and ampulla of the oviduct in pregnant heifers at a critical time-point coinciding with embryonic genome activation.

\section{Materials and methods}

\section{Animals and treatments}

All experimental procedures involving animals were licensed by the Department of Health and Children, Ireland. Protocols were in accord with the Cruelty to Animals Act (Ireland 1897) and the European Community Directive 86/609/EC and were sanctioned by the Institutional Animal Research Ethics Committee.
All animals were housed indoors on a slatted floor and were fed a diet consisting of grass and maize silage supplemented with a standard beef ration. Crossbred beef heifers $(n=19$, predominantly Charolais and Limousin cross; mean \pm S.E.M. $23.00 \pm 0.74$ months old; mean \pm s.E.M. $583.26 \pm 12.45 \mathrm{~kg}$ ) were synchronized using a 7-day Controlled Internal Drug Release device (CIDR 1.38g; Pfizer) together with $0.02 \mathrm{mg}$ of a GNRH agonist (buserelin, Receptal; Intervet, Dublin, Ireland) at CIDR insertion and $15 \mathrm{mg}$ of a prostaglandin F2 $\alpha$ analogue (Prosolvin; Intervet, Dublin, Ireland) the day before CIDR removal. To detect signs of oestrus, heifers were observed four times per day commencing $30 \mathrm{~h}$ after CIDR withdrawal, and only those recorded in standing oestrus (Day 0) $(n=17)$ were used. Heifers were randomly allocated to one of two groups: (a) non-bred or cyclic $(n=6)$ or (b) pregnant $(n=11)$, which were artificially inseminated 12 and $24 \mathrm{~h}$ after first sign of oestrus, with frozen-thawed semen from a bull of proven fertility.

\section{Sample collection}

On Day 3 after oestrus (mean \pm S.E.M., $3.09 \pm 0.04$ days), animals were slaughtered in a commercial abattoir. The reproductive tract was removed, sealed in a plastic bag, transported to the laboratory on ice and processed within $3.5 \mathrm{~h}$ after slaughter (mean \pm S.E.M., $3.60 \pm 0.25$ h). Both oviducts were trimmed free of tissue. After removal of the infundibulum and the uterotubal junction, the oviduct was divided into two parts through the ampullary-isthmic junction, identified where the oviduct diameter first exhibited a marked reduction in size (going from ampulla to isthmus, Fig. 1) (Kobayashi et al. 2013). The ampulla and isthmus of both the ipsilateral and contralateral oviduct were flushed with $500 \mu \mathrm{L}$ PBS to confirm the presence of an unfertilized oocyte or an embryo under a microscope. After flushing each part, the ampulla and isthmus sections of both oviducts were opened longitudinally and gently scraped with a blade to recover epithelial cells. Representative cell samples from both regions were fixed for flow cytometry analysis. The remainder of the cells were snap frozen and stored at $-80^{\circ} \mathrm{C}$.

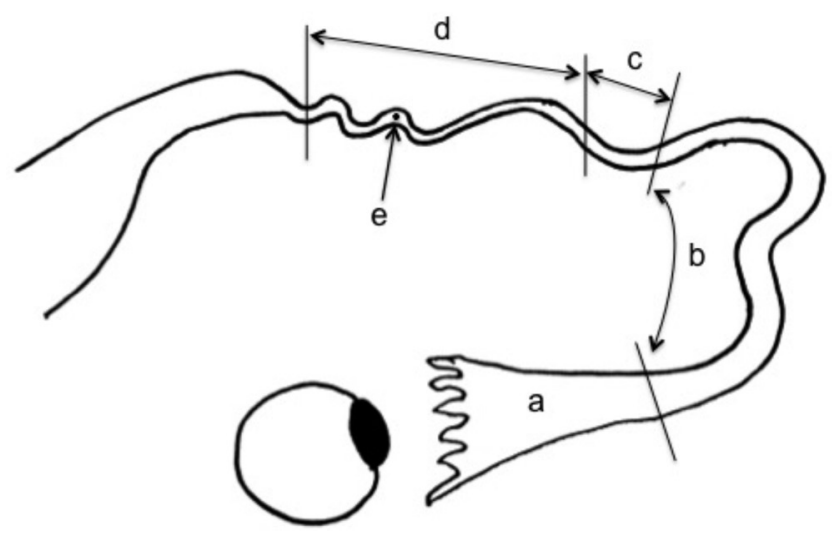

Figure 1 Schematic illustration indicating how the different parts of the oviducts were separated. a, infundibulum; b, ampulla; c, ampullary-isthmic junction; d, isthmus; e, oocyte/embryo found in the isthmus. Purity of epithelial cells from the ampulla and isthmus regions was verified using flow cytometry before microarray analysis. 
Samples from 5 non-bred (cyclic) heifers with a confirmed non-fertilized oocyte and 5 pregnant heifers with an 8-cell stage embryo were used for microarray and quantitative realtime PCR analysis (qPCR).

\section{Flow cytometry analysis}

Cells from ampulla and isthmus were fixed with $4 \%$ paraformaldehyde and permeabilized by incubation for $5 \mathrm{~min}$ with 0.5 Triton $(\times 100)$. Incubation with primary antibodies (antibovine-pancadherin (C1821), anti-bovine-pancytokeratin (C2931) and anti-bovine-vimentin (V2258), all from Sigma) was carried out overnight followed by anti-mouse alexa488 secondary antibody. Samples were analysed in a Cytomics FC 500 MPL cytometer (Beckman Coulter, Alcobendas, Madrid, Spain). Negative controls were included for all the samples analysed and they are represented as the pink plots as shown in Fig. 2. Cells labelled with cadherin and cytokeratin were considered as epithelial cells while those labelled with vimentin were classified as connective tissue cells (Fig. 2).

\section{RNA extraction and microarray hybridization}

Total RNA was extracted from oviductal cell samples by the Trizol method as per manufacturer's instructions (Invitrogen). After a column DNAse digestion and RNA clean up, (Qiagen) both the quality and quantity of the RNA was determined using the Agilent Bioanalyzer (Agilent Technologies) and the NanoDrop 1000 (Thermo Fisher Scientific), respectively. Only samples with an RNA Integrity Number of greater than 8.0 were used for microarray analysis. Transcriptomic analysis was carried out using the Bovine Gene ST 1.0 microarray (Affymetrix). Total RNA (150ng) was used for reverse transcription using the Ambion WT Expression Kit (Life Technologies) while the rest was stored for microarray validation analysis by qPCR. All samples were processed with the appropriate amount of Poly-A RNA controls from the Affymetrix GeneChip Poly-A RNA Control Kit (Affymetrix) as specified within the Ambion user manual. Purified cDNA $(5.5 \mu \mathrm{g})$ was fragmented and labelled using the GeneChip WT Terminal Labelling Kit and fragmentation was verified using the Agilent 2100 bioanalyzer. Hybridization was carried out according to the Affymetrix user manual. Briefly, fragmented, biotin-labelled cDNA was hybridized to the Affymetrix Bovine Gene ST 1.0 microarray as described within the Encore Biotin Module user's guide appendix. Samples were hybridized for $16 \mathrm{~h}$ at $45^{\circ} \mathrm{C}$ in a GeneChip Hybridization Oven 640 while rotating at $45 \mathrm{rpm}$. Microarrays were processed using the Affymetrix GeneChip Fluidic Station 450. Staining was carried out with streptavidin-conjugated phycoerythrin (SAPE) followed by amplification with a biotinylated anti-streptavidin antibody and by a second round of SAPE before scanning using a GeneChip Scanner 3000 (Affymetrix) and GeneChip Command Console software. The data are available in the Gene Expression Omnibus (GEO: GSE75442).

\section{Quantitative real-time PCR ( $P$ PCR)}

Validation of the microarray results was performed by qPCR analysis of 12 of the top up- and down-regulated genes selected from the list of differentially expressed genes (DEGs) obtained from the comparison between the ipsilateral isthmus and ampulla of pregnant animals. Total RNA (1000 ng) from the samples used for microarray analysis was reverse transcribed into cDNA using the High Capacity Reverse Transcription Kit as per manufacturer's instruction (Applied Biosystems). All primers were designed using Primer-BLAST software (www. ncbi.nlm.nih.gov/tools/primersblast/) to span exon-exon boundaries when possible. All qPCR reactions were carried out in duplicate on the Rotorgene 6000 Real Time Cycler TM (Corbett Research, Sydney, Australia) by adding $5 \mathrm{ng}$ of each sample to the PCR mix (GoTaq qPCR Master Mix, Promega) containing the specific primers selected to amplify gastrinreleasing peptide $(G R P)$, ribonuclease, RNase A family, 1 (pancreatic) (RNASE1), neuropilin (NRP) and tolloid (TLL)-like 1 (NETO1), aldo-keto reductase family 1, member B1 (aldose reductase) $(A K R 1 B 1)$, low density lipoprotein receptor-related protein 2 (LRP2), glycoprotein M6B (GPM6B), connective tissue growth factor (CTGF), cyclin B1 (CCNB1), lysozyme (LYZ1), prostaglandin D2 synthase $21 \mathrm{kDa}$ (brain) (PTCDS), pleckstrin homology domain containing, family G (with RhoGef domain) member 7 (PLEKHG7) and flavin containing monooxygenase 2 (non-functional) (FMO2). Primer sequences and the approximate sizes of the amplified fragments of all
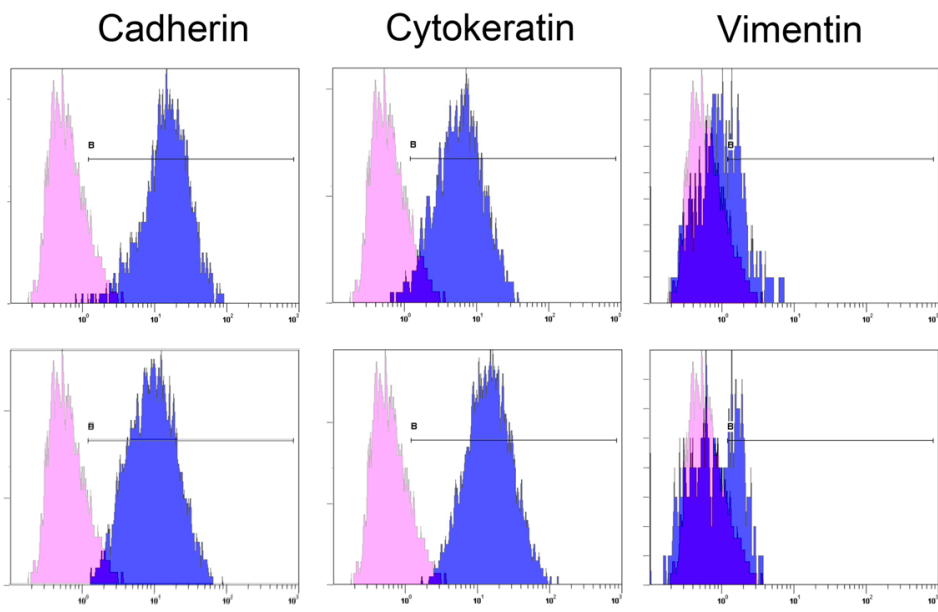

Ampulla

Isthmus

Figure 2 Flow cytometry analysis of ampullary and isthmic oviductal cells stained with Cadherin, Cytokeratin and Vimentin markers. Negative control is depicted as a pink plot. 
transcripts are given in Supplementary Table 1 (see section on supplementary data given at the end of this article). Cycling conditions were $94^{\circ} \mathrm{C}$ for $3 \mathrm{~min}$ followed by 35 cycles of $94^{\circ} \mathrm{C}$ for $15 \mathrm{~s}, 56^{\circ} \mathrm{C}$ for $30 \mathrm{~s}, 72^{\circ} \mathrm{C}$ for $10 \mathrm{~s}$ and $10 \mathrm{~s}$ of fluorescence acquisition. Each pair of primers were tested to achieve efficiencies close to 1 and then the comparative cycle threshold (CT) method was used to quantify expression levels as described previously (Schmittgen \& Livak 2008). To avoid primer dimer artefacts, fluorescence was acquired in each cycle at a temperature higher than the melting temperature of primer dimmers (specific for each product, $76-86^{\circ} \mathrm{C}$ ). Then, the threshold cycle or the cycle during the log-linear phase of the reaction at which fluorescence increased above background was determined for each sample. The $\Delta$ CT value was determined by subtracting the endogenous control (an average of $H 2 A Z, A C T B$ and 18S) CT value for each sample from each gene CT value of the sample. Calculation of $\Delta \Delta C T$ involved using the highest sample $\Delta C T$ value (i.e. the sample with the lowest target expression) as a constant to subtract from all other $\Delta$ CT sample values. Fold-changes in the relative gene expression of the target were determined using the equation $2^{-\Delta \Delta C T}$. Positive controls (DNA), a negative control (distilled water), and RT-negative controls (total RNA sample) were included in each run.

\section{Data analysis}

For microarray data, the raw signal intensities were read into $\mathrm{R}$ and pre-processed using functions of both Affy and GCRMA packages of the BioConductor project (Gentleman et al. 2004). Hierarchical clustering analysis was carried out to determine the greatest source of variation in the tissue samples. Lists of DEGs were determined by Limma package (Smyth 2005) employing linear modelling and an empirical Bayes framework to shrink the variance of measurements on each probe set. A modified $t$-test was then carried out and all $P$-values were adjusted for multiple testing using Benjamini and Hochberg false discovery rate method. Lists of DEGs were selected on the basis of an adjusted $P$-value of $<0.05$ (4011 DEGs). Given the large number of DEGs obtained with this $P$-value, a more stringent level of $P<0.01$ was used to generate the list of differentially expressed probe sets inputted for the gene ontology (GO) overrepresentation analysis (2287 DEGs).

Data obtained by qPCR were analysed using Sigma Stat (Jandel Scientific, San Rafael, CA, USA) software package. Student's $t$-test was performed to study the differences in expression values between isthmus and ampulla regions.

\section{Gene ontology analysis}

Gene ontology analysis was carried out using DAVID (Huang da et al. 2009a,b). The entire genome of Bos taurus was used as the background list. The list of DEGs with a more stringent level of $P<0.01$ was used to limit the input to DAVID to achieve meaningful overrepresented data. From the output obtained, GO FAT terms were used instead of GO ALL, because the FAT category filters out the very broad GO terms based on a measured specificity of each term to yield more specific terms. Using these data, differences in biological processes (BP), molecular function (MF), cellular component (CC) and KEGG pathways were analysed.

\section{Results}

Flow cytometry analyses revealed a homogenous population (over 90\%) of cadherin- and cytokeratinpositive cells (Fig. 2).

\section{Changes in oviduct gene expression}

In order to test the effect of region (ampulla vs isthmus), localization relative to the $\mathrm{CL}$ (ipsilateral vs contralateral), presence of sperm and presence of an embryo, the following array comparisons were carried out:

- Pregnant Ipsilateral Isthmus vs Pregnant Contralateral Isthmus: effect of embryo on the oviduct without potential confounding effect of sperm.

- Cyclic Ipsilateral Isthmus vs Cyclic Contralateral Isthmus: local effect of the CL on the oviduct.

- Pregnant Contralateral Isthmus vs Cyclic Contralateral Isthmus: potential effect of sperm.

- Pregnant Ipsilateral Isthmus vs Pregnant Ipsilateral Ampulla: see if the effect is local within the ipsilateral oviduct.

- Pregnant Ipsilateral Isthmus vs Cyclic Ipsilateral Isthmus: effect of embryo and sperm on the oviduct. This comparison resulted in 0 DEGs and has been recently published as part of a separate study (Maillo et al. 2015); therefore it will not be discussed in this study.

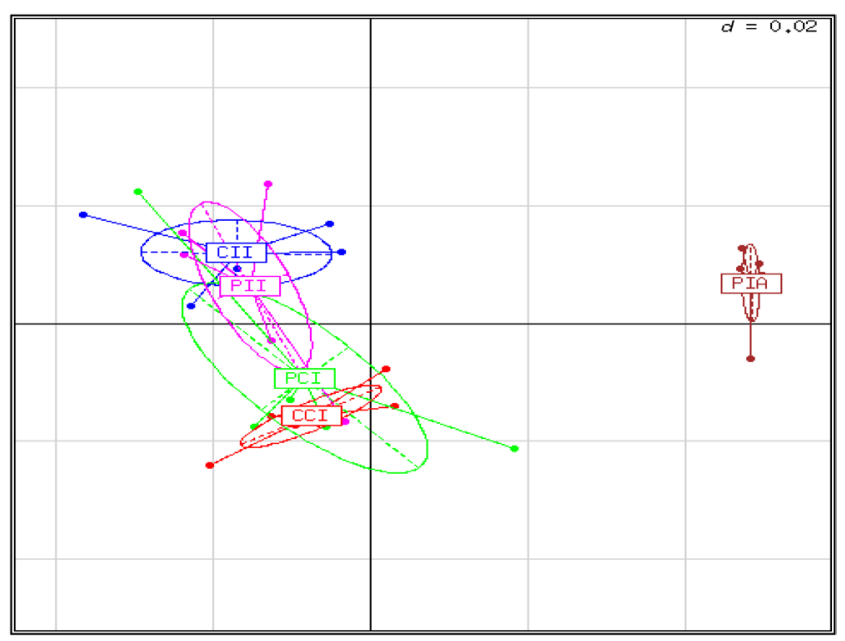

Figure 3 Correspondence analysis demonstrating the source of greatest variation in the oviduct transcriptional profile. Each dot represents all the transcripts expressed on one microarray representing one tissue site from one animal. CII, cyclic ipsilateral isthmus; PII, pregnant ipsilateral isthmus; $\mathrm{CCl}$, cyclic contralateral isthmus; $\mathrm{PCl}$, pregnant contralateral isthmus; $\mathrm{PIA}$, pregnant ipsilateral ampulla. 


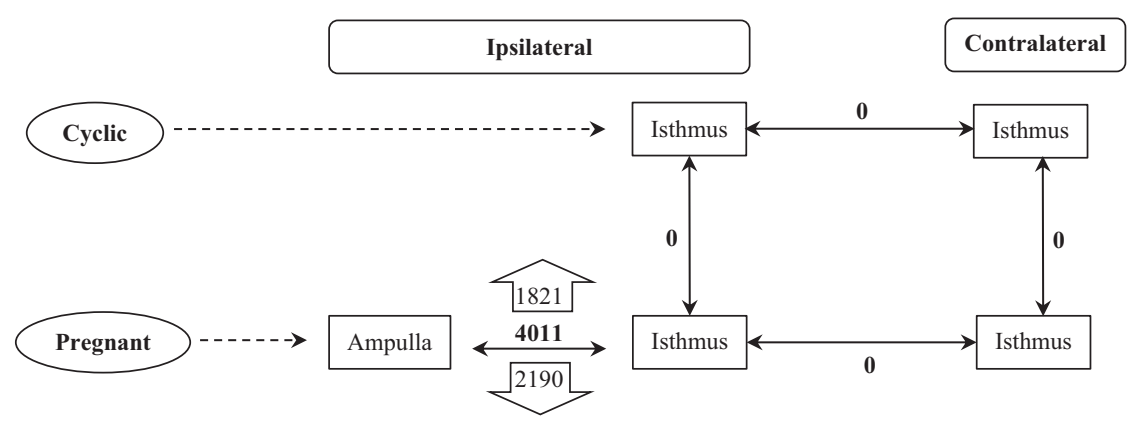

Figure 4 Overview of the groups compared in the microarray analysis. Numbers represent the differentially expressed genes in each comparison. Numbers in arrows refer to up- or down-regulated genes in the isthmus of pregnant heifers $(P<0.05)$. Further details referred in text.
Correspondence analysis revealed that region of the oviduct was the factor that contributed most to the variation in overall transcriptional profile of the oviductal epithelium, i.e. all samples recovered from the isthmus, irrespective of pregnancy status or location relative to the $\mathrm{CL}$ clustered together, whereas samples analysed from the ampulla clearly segregated from the rest (Fig. 3).

\section{Factors that affect the transcriptome of the oviduct}

Under our experimental conditions, proximity to the $\mathrm{CL}$ (i.e. cells from the oviduct ipsilateral vs contralateral to the $\mathrm{CL}$ ) did not affect the transcriptome of the isthmus, irrespective of whether the heifer was cyclic or pregnant. However, region within the oviduct significantly affected the pattern of gene expression; when the ampulla and isthmus of the oviduct ipsilateral to the $C L$ in pregnant animals were compared, 4011 DEGs were identified $(P<0.05)$ (Fig. 4$)$ and with a more stringent level of $P<0.01$ the number of DEGs was 2287 (Fig. 5).

Of the 2287 DEGs identified between the isthmus and ampulla, 1132 were upregulated and 1155 were downregulated in the isthmus region. A list of the top twenty up- and down-regulated genes is shown in Fig. 5. In addition, of the 1132 genes upregulated in the isthmus, 403 had a fold change equal or greater than 2 and 30 exhibited more than a tenfold change. However, of the 1155 DEGs downregulated in the isthmus, 245 had a fold change equal or greater than 2 with only one gene changing more than tenfold (Supplementary Table 2).

Analysis of the GO terms associated with those genes indicated that 203 and 126 biological processes (BP) (containing a minimum of two genes) were overrepresented in the isthmus and the ampulla, respectively. Of these BP, 24 were common between isthmus and ampulla, including (1) phosphate metabolic process (47 and 44 genes in isthmus and ampulla, respectively); (2) intracellular signalling cascade (42 and 32 genes); (3) ion transport (38 and 33 genes); (4) phosphorylation (38 and 36 genes); and (5) regulation of cell proliferation (26 and 23 genes). From the different $\mathrm{BP}$ in each region, in the isthmus, synthesis of nitrogen compounds (24), lipids (17), nucleotides (15), steroids (10) and cholesterol (10) as well as vesicle-mediated transport (31), cell cycle (17), apoptosis (16), endocytosis (13) and exocytosis (7) were considered as possible candidates to provide an optimal environment to support early embryo development (Supplementary Table 3.1). In the ampulla, cell motion (19), cell motility (17) and cell migration (15), DNA repair (11), calcium ion homeostasis (9), carbohydrate biosynthetic process (7) and regulation of cilium movement (2) and beat frequency (2) involved in ciliary motility were taking into consideration for oocyte transport and maintenance (Supplementary Table 3.2). In the molecular function category nucleotide binding (103), protein kinase activity (34) and GTPase regulator activity (24) were overrepresented in the isthmus (Supplementary Table 3.3) whereas ion binding (142), cation binding (139) and metal ion binding (136) were overrepresented in the ampulla (Supplementary Table 3.4). In relation to the cellular component, the upregulated genes in the isthmus were expressed mainly in the Golgi apparatus (31), cytoplasmic vesicle (24) and vesicle (24) (Supplementary Table 3.5) while cytoskeleton (39), cell projection (28) and cilium (10) were the places overrepresented in the ampulla (Supplementary Table 3.6).

In the KEGG pathway analysis, 24 pathways were present in the isthmus and 11 in the ampulla, with

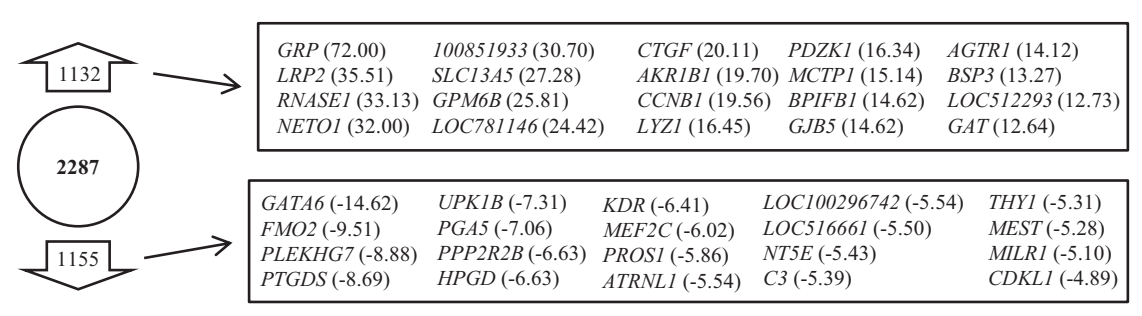

www.reproduction-online.org
Figure 5 Illustration of differentially expressed genes between isthmus and ampulla of the ipsilateral oviduct in pregnant heifers showing the top 40 up- and down-regulated genes in the isthmus (1132 and 1155, respectively) $(P<0.01)$. Values in parentheses indicate the fold-change difference for each gene. Complete gene lists can be found in Supplementary Table 2. 


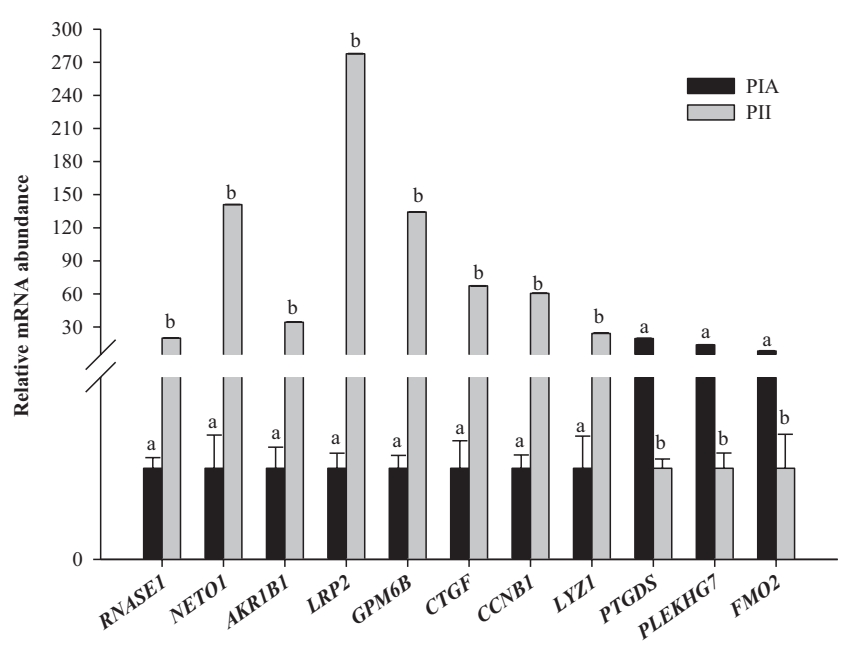

Figure 6 Quantitative real-time PCR analysis of selected genes for microarray validation across 22 comparisons (11 genes $\times 2$ groups) between pregnant ipsilateral isthmus (PII) and pregnant ipsilateral ampulla (PIA). Quantification was normalized to the endogenous control (an average of $H 2 A Z$, ACTB and $18 S)(P<0.001)$. GRP was excluded from the figure because its relative mRNA expression was 2322 higher in the isthmus compared with the ampulla, thereby too high to be represented. For each transcript, bars with different superscripts differ significantly $(P<0.05)$.

WNT- and VEGF-signalling pathways overrepresented in the isthmus and MAPK- and calcium-signalling overrepresented in the ampulla (Supplementary Table 3.7 and 3.8 respectively).

\section{qPCR microarray validation}

Twelve genes (9 higher: GRP, RNASE1, NETO1, AKR1B1, LRP2, GPM6B, CTGF, CCNB1, LYZ1; and 3 lower: PTGDS, PLEKHG7 and FMO2 in the isthmus) were assessed by qPCR. The results were consistent with the results from the microarray analysis (Fig. 6).

\section{Discussion}

The main findings of this study are that: (1) in pregnant heifers, major differences in gene expression exist between the ampulla and isthmus regions of the oviduct ipsilateral to the $\mathrm{CL}$; and (2) gene expression of the oviduct in pregnant or cyclic heifers is not modified by exposure to sperm 3 days previously or by proximity to the CL.

The oviduct is the organ in which sperm capacitation, fertilization and early embryo development take place. In some studies, it has been found that sperm can induce modifications in the gene expression profile of the oviduct epithelium (Fazeli et al. 2004, Alminana et al. 2014). At first glance, this may appear to conflict with our results; however, it is important to mention that the time when the tissues in these studies were collected was different from the current study. For example, Fazeli et al. (2004) evaluated the effect of the sperm in mice as early as $6 \mathrm{~h}$ after mating; Georgiou et al. (2007) studied the effect of the gametes on the porcine oviduct proteome $24 \mathrm{~h}$ after artificial insemination or $18 \mathrm{~h}$ after the incubation of sow oviducts with sperm in vitro (Georgiou et al. 2005); similar findings have been detected $24 \mathrm{~h}$ after co-incubating sperm with oviductal cells in vitro (Li et al. 2010). In our study, samples were collected 3 days after artificial insemination, by which time any effect of the sperm may have disappeared.

In relation to the proximity of the oviduct region to the $\mathrm{CL}$ (i.e. ipsilateral versus contralateral oviduct), Bauersachs et al. (2003) found a small number of DEGs (35) between the ipsilateral and contralateral oviducts in cyclic animals at Day 3.5 after oestrus. In that study, suppressive subtractive hybridization and cDNA microarray hybridization were used and also the cells were taken from the entire oviduct epithelium, as opposed to where the embryo would have been located. The differences in the technique and the origin of the samples may explain why we did not find differences caused by the presence of the CL.

In this study, the only differences detected in the transcriptome of the oviduct were those between the isthmus and the ampulla of pregnant animals (2287 DEGs, of which 1132 were higher in the isthmus and 1155 higher in the ampulla). According to gene ontology (GO) analysis, in the ampulla some of the genes from the over-represented categories were related with cell motion, motility and migration, ciliary motility and beat frequency. These categories may be related with the greater population of ciliated cells there facilitating the transport of the oocyte to the site of fertilization (Halbert et al. 1989). In the isthmus, genes were related with vesicle-mediated transport, endocytosis, exocytosis, cell cycle and apoptosis, likely involved in the provision of an optimal environment to support early embryo development. In a recent study by Cerny et al. (2015), DEGs have been found between the ampulla and isthmus and also between the follicular and luteal phase (Day 11-12 after oestrus). Comparison of our data with those data reveals some overlap in biological processes and pathways in common, such as the complement system in the ampulla or Wnt signalling pathway and axon guidance in the isthmus. The lack of more genes, biological processes or pathways in common may be due to the fact that in our study the tissues were collected in the early luteal phase (Day 3) when the embryo is still in the oviduct.

Lapointe and Bilodeau (2003) found that the expression of antioxidants during the oestrous cycle differs between the ampulla and isthmus, with higher GPX2 expression in the ampulla and GPX3 in the isthmus, similar to what was observed in this study. These antioxidants belong to the family of glutathione peroxidases, which 
are responsible for metabolizing $\mathrm{H}_{2} \mathrm{O}_{2}$, one of the reactive oxygen species (ROS). It is likely that a balance must exist in the oviduct between ROS and antioxidants as it has been found that ROS decrease the motility of bovine sperm in vitro (Bilodeau et al. 2000), and also reduce the ability of sperm to fuse with the egg plasma membrane (Mammoto et al. 1996). However, sperm binding to the zona pellucida is promoted by low levels of ROS and is inhibited by antioxidants (Aitken et al. 1989). Therefore, the production of ROS controlled by the reproductive tract could be a key factor in successful fertilization and subsequent implantation (Lapointe \& Bilodeau 2003).

The most DEG in the isthmus was GRP with a fold change of 72 compared with the ampulla region. $G R P$ is a peptide that stimulates gastrin release. In the reproductive tract, GRP has been found in pregnant uterus of humans (Xiao et al. 1996) and sheep (Fraser et al. 1992). In sheep, it is highly expressed in the glandular epithelium of the uterus during pregnancy as well as during the oestrous cycle and in several foetal tissues (Whitley et al. 1998, 2002). In addition, Song et al. (2008) described that GRP expression in the ovine uterus was modified by progesterone and interferon-tau. In cattle, GRP was upregulated during oestrus compared with dioestrus (Bauersachs et al. 2004), suggesting a role during the early stages of embryo development. Notably, GRP is processed into different bioactive peptides, including GRP1-27, GRP18-27, and a C-terminus, that affect cell proliferation and migration in other tissue and cell types (Song et al. 2008).

Connective tissue growth factor (CTGF) is a cysteinerich protein that is expressed in multiple tissues and has been linked to embryo development, cell proliferation, mitosis, migration, adhesion, matrix production, differentiation and maintenance of normal cell and connective tissue function (Brigstock et al. 1997, De Winter et al. 2008). In the uterus of mice and humans, during the luteal phase, CTGF is expressed in luminal and glandular epithelium (Surveyor et al. 1998, Uzumcu et al. 2000). During early pregnancy, this gene is upregulated in the uterus of mice from Day 1.5 to 3.5 compared with Day 4.5 (Surveyor et al. 1998) and in the endometrium of pregnant cattle compared with non-pregnant cattle at Day 13, 16 and 18 post oestrus (Klein et al. 2006, Forde et al. 2010). In mice embryos, CTGF expression was higher at Day 5.5 and 6.5 compared with Day 4.5 after implantation, particularly in the embryonic ectoderm cells, but was also differentially distributed throughout the various embryonic structures (Surveyor et al. 1998). CTGF protein has also been detected in uterine flushings of mice and pigs (Brigstock et al. 1997, Surveyor et al. 1998). Therefore, CTGF may play an important role in cell proliferation of the oviduct epithelium, which could have an effect on the embryo.

The aldose reductase gene (AKR1B1) encodes the enzyme aldolase reductase responsible for metabolizing progesterone, and is involved in the production of prostaglandin $\mathrm{F} 2 \alpha$ by the endometrium in cattle and humans (Madore et al. 2003, Bresson et al. 2011). This gene was upregulated in biopsies derived from blastocysts which failed to establish a pregnancy after transfer (El-Sayed et al. 2006). By contrast, in another study with the use of bovine OF before fertilization in vitro, it was found that expression of AKR1B1 was affected by the quality of the blastocysts (CebrianSerrano et al. 2013). The protein encoded by AKR1B1 has also been found in the uterine luminal fluid of pregnant heifers on Day 16 (Forde et al. 2014). In addition, high glucose concentrations in culture media could lead to upregulation of aldose reductase and subsequent accumulation of sorbitol in cytoplasm and activation apoptotic pathways (Wirtu et al. 2003). Therefore, as glucose requirements are very low during the first stages of embryo development (Thompson 2000), AKR1B1 may be involved in maintaining low glucose levels in the oviduct at this time.

Cyclin B1 (CCNB1) is involved in the generation of maturation promoting factor which drives oocytes into and through meiosis (Marangos \& Carroll 2004). This gene is accumulated and stored during oogenesis (Rekik et al. 2011) until it is activated to complete the maturation of the oocyte. Transcripts for CCNB1 are abundant in bovine oocytes and embryos up to 4-cell stage, after which they decrease to very low levels in the 8-cell embryo, when embryonic genome activation begins, and remain low up to the blastocyst stage (Tremblay et al. 2005). Apart from the specific effect of CCNB1 on the maturation of the oocyte, the accumulation of CCNB1 is necessary for the cell cycle progression through $\mathrm{G}_{2}$ to mitosis, i.e. to start mitosis (Scaife 2004). Therefore CCNB1 expression in the embryo is due to maternally derived mRNA up to 4-cell stage, while in later stages the appropriate CCNB1 requirements can be provided by the oviduct.

Prostaglandin D2 synthase $21 \mathrm{kDa}$ (PTGDS or PGDS) synthetizes PGD2 and induces sleep, allergic responses, inhibition of platelet aggregation, and relaxation of vascular and non-vascular smooth muscle (Kengni et al. 2007). There are two types of PGD2 synthase: lipocalin type PGDS (L-PGDS) and hematopoietic PGDS (H-PGDS). H-PGDS is highly expressed in the rat oviduct and also in human uterine epithelial cells, endometrial gland cells and trophoblast (Kanaoka et al. 1997, Michimata et al. 2002). Ptgds is upregulated during pregnancy in rats and it has been suggested that its expression is dependent on the presence of an embryo (Kengni et al. 2007). In addition, in humans PGD2 may contribute to the maintenance of pregnancy by suppressing antigen presentation (Michimata et al. 2002). The upregulation of PTCDS in the ipsilateral ampulla of pregnant animals in the current study may suggest an immune role for this gene at the time of zygote formation. 


\section{Conclusion}

The results of the current study provide a comprehensive insight into the transcriptional differences present between the isthmus and ampulla regions of the oviduct at the time when the embryo is exposed to these environments. These alterations in gene expression may reflect morphological and functional differences between these two distinct regions of the oviduct that in future experiments may help us to improve in vitro embryo production systems.

\section{Supplementary data}

This is linked to the online version of the paper at http://dx.doi. org/10.1530/REP-16-0074.

\section{Declaration of interest}

The authors declare that there is no conflict of interest that could be perceived as prejudicing the impartiality of the research reported.

\section{Funding}

Funding was received from the Spanish Ministry of Economy and Competitiveness (AGL2012-37510 to D Rizos and AGL2012-39652-C02-01 to A Gutierrez-Adan). N Forde and $\mathrm{P}$ Lonergan were supported by funding from the European Union Seventh Framework Programme FP7/2007-2013 under grant agreement $n^{\circ} 312097$ ('FECUND'). V Maillo was partly supported by Short Term Scientific Mission from COSTEPIGENOMICS (COST-STSM- FA1201-010313-027947).

\section{References}

Abe H 1996 The mammalian oviductal epithelium: regional variations in cytological and functional aspects of the oviductal secretory cells. Histology and Histopathology 11 743-768.

Aitken RJ, Clarkson JS \& Fishel S 1989 Generation of reactive oxygen species, lipid peroxidation, and human sperm function. Biology of Reproduction 41 183-197. (doi:10.1095/biolreprod41.1.183)

Alminana C, Caballero I, Heath PR, Maleki-Dizaji S, Parrilla I, Cuello C, Gil MA, Vazquez JL, Vazquez JM, Roca J et al. 2014 The battle of the sexes starts in the oviduct: modulation of oviductal transcriptome by $\mathrm{X}$ and Y-bearing spermatozoa. BMC Genomics 15 293. (doi:10.1186/14712164-15-293)

Areekijseree M 2003 Scanning electron microscopy observations of porcine ampullary oviductal epithelial cells. Silpakorn University International Journal 3 266-276.

Bauersachs S, Blum H, Mallok S, Wenigerkind H, Rief S, Prelle K \& Wolf E 2003 Regulation of ipsilateral and contralateral bovine oviduct epithelial cell function in the postovulation period: a transcriptomics approach. Biology of Reproduction 68 1170-1177. (doi:10.1095/ biolreprod.102.010660)

Bauersachs S, Rehfeld S, Ulbrich SE, Mallok S, Prelle K, Wenigerkind H, Einspanier R, Blum H \& Wolf E 2004 Monitoring gene expression changes in bovine oviduct epithelial cells during the oestrous cycle. Journal of Molecular Endocrinology 32 449-466. (doi:10.1677/ jme.0.0320449)

Bilodeau JF, Chatterjee S, Sirard MA \& Gagnon C 2000 Levels of antioxidant defenses are decreased in bovine spermatozoa after a cycle of freezing and thawing. Molecular Reproduction and Development $\mathbf{5 5}$ 282-288. (doi:10.1002/(ISSN)1098-2795)

Bresson E, Boucher-Kovalik S, Chapdelaine P, Madore E, Harvey N, Laberge PY, Leboeuf M \& Fortier MA 2011 The human aldose reductase AKR1B1 qualifies as the primary prostaglandin $F$ synthase in the endometrium. Journal of Clinical Endocrinology and Metabolism 96 210-219. (doi:10.1210/jc.2010-1589)

Brigstock DR, Steffen CL, Kim GY, Vegunta RK, Diehl JR \& Harding PA 1997 Purification and characterization of novel heparin-binding growth factors in uterine secretory fluids. Identification as heparin-regulated $\mathrm{Mr}$ 10,000 forms of connective tissue growth factor. Journal of Biological Chemistry 272 20275-20282. (doi:10.1074/jbc.272.32.20275)

Cebrian-Serrano A, Salvador I, Garcia-Rosello E, Pericuesta E, PerezCerezales S, Gutierrez-Adan A, Coy P \& Silvestre MA 2013 Effect of the bovine oviductal fluid on in vitro fertilization, development and gene expression of in vitro-produced bovine blastocysts. Reproduction in Domestic Animals 48 331-338. (doi:10.1111/j.14390531.2012.02157.x)

Cerny KL, Garrett E, Walton AJ, Anderson LH \& Bridges PJ 2015 A transcriptomal analysis of bovine oviductal epithelial cells collected during the follicular phase versus the luteal phase of the estrous cycle. Reproductive Biology and Endocrinology 13 84. (doi:10.1186/s12958015-0077-1)

De Winter P, Leoni P \& Abraham D 2008 Connective tissue growth factor: structure-function relationships of a mosaic, multifunctional protein. Growth Factors 26 80-91. (doi:10.1080/08977190802025602)

El-Sayed A, Hoelker M, Rings F, Salilew D, Jennen D, Tholen E, Sirard MA, Schellander K \& Tesfaye D 2006 Large-scale transcriptional analysis of bovine embryo biopsies in relation to pregnancy success after transfer to recipients. Physiological Genomics 28 84-96. (doi:10.1152/ physiolgenomics.00111.2006)

Enright BP, Lonergan P, Dinnyes A, Fair T, Ward FA, Yang X \& Boland MP 2000 Culture of in vitro produced bovine zygotes in vitro vs in vivo: implications for early embryo development and quality. Theriogenology 54 659-673. (doi:10.1016/S0093-691X(00)00381-2)

Fazeli A, Affara NA, Hubank M \& Holt WV 2004 Sperm-induced modification of the oviductal gene expression profile after natural insemination in mice. Biology of Reproduction 71 60-65. (doi:10.1095/ biolreprod.103.026815)

Forde N, Spencer TE, Bazer FW, Song G, Roche JF \& Lonergan P 2010 Effect of pregnancy and progesterone concentration on expression of genes encoding for transporters or secreted proteins in the bovine endometrium. Physiological Genomics 41 53-62. (doi:10.1152/ physiolgenomics.00162.2009)

Forde N, McGettigan PA, Mehta JP, O'Hara L, Mamo S, Bazer FW, Spencer T \& Lonergan P 2014 Proteomic analysis of uterine fluid during the pre-implantation period of pregnancy in cattle. Reproduction 147 575-587. (doi:10.1530/REP-13-0010)

Fraser M, Carter AM, Challis JR \& McDonald TJ 1992 Gastrin releasing peptide immunoreactivity is present in ovine amniotic fluid and fetal and maternal circulations. MRC Group in Fetal and Neonatal Health and Development. Endocrinology 131 2033-2035. (doi:10.1210/ endo.131.4.1396347)

Gabler C, Einspanier A, Schams D \& Einspanier R 1999 Expression of vascular endothelial growth factor (VEGF) and its corresponding receptors (flt-1 and flk-1) in the bovine oviduct. Molecular Reproduction and Development 53 376-383. (doi:10.1002/(ISSN)1098-2795)

Gad A, Hoelker M, Besenfelder U, Havlicek V, Cinar U, Rings F, Held E, Dufort I, Sirard MA, Schellander K et al. 2012 Molecular mechanisms and pathways involved in bovine embryonic genome activation and their regulation by alternative in vivo and in vitro culture conditions. Biology of Reproduction 87 100. (doi:10.1095/biolreprod.112.099697)

Gentleman RC, Carey VJ, Bates DM, Bolstad B, Dettling M, Dudoit S, Ellis B, Gautier L, Ge Y, Gentry J et al. 2004 Bioconductor: open software development for computational biology and bioinformatics. Genome Biology 5 R80. (doi:10.1186/gb-2004-5-10-r80)

Georgiou AS, Sostaric E, Wong CH, Snijders AP, Wright PC, Moore HD \& Fazeli A 2005 Gametes alter the oviductal secretory proteome. Molecular \& Cellular Proteomics 4 1785-1796. (doi:10.1074/mcp. M500119-MCP200)

Georgiou AS, Snijders AP, Sostaric E, Aflatoonian R, Vazquez JL, Vazquez JM, Roca J, Martinez EA, Wright PC \& Fazeli A 2007 Modulation 
of the oviductal environment by gametes. Journal of Proteome Research 6 4656-4666. (doi:10.1021/pr070349m)

Halbert SA, Becker DR \& Szal SE 1989 Ovum transport in the rat oviductal ampulla in the absence of muscle contractility. Biology of Reproduction 40 1131-1136. (doi:10.1095/biolreprod40.6.1131)

Horne AW, Phillips JA 3rd, Kane N, Lourenco PC, McDonald SE, Williams AR, Simon C, Dey SK \& Critchley HO 2008 CB1 expression is attenuated in Fallopian tube and decidua of women with ectopic pregnancy. PLoS ONE 3 e3969. (doi:10.1371/journal.pone.0003969)

Huang da W, Sherman BT \& Lempicki RA 2009a Bioinformatics enrichment tools: paths toward the comprehensive functional analysis of large gene lists. Nucleic Acids Researach 37 1-13. (doi:10.1093/nar/gkn923)

Huang da W, Sherman BT \& Lempicki RA 2009b Systematic and integrative analysis of large gene lists using DAVID bioinformatics resources. Nature Protocols 4 44-57. (doi:10.1038/nprot.2008.211)

Hugentobler SA, Diskin MG, Leese HJ, Humpherson PG, Watson T, Sreenan JM \& Morris DG 2007a Amino acids in oviduct and uterine fluid and blood plasma during the estrous cycle in the bovine. Molecular Reproduction and Development 74 445-454. (doi:10.1002/ mrd.20607)

Hugentobler SA, Morris DG, Sreenan JM \& Diskin MG 2007b lon concentrations in oviduct and uterine fluid and blood serum during the estrous cycle in the bovine. Theriogenology 68 538-548. (doi:10.1016/j. theriogenology.2007.04.049)

Hugentobler SA, Sreenan JM, Humpherson PG, Leese HJ, Diskin MG \& Morris DG 2010 Effects of changes in the concentration of systemic progesterone on ions, amino acids and energy substrates in cattle oviduct and uterine fluid and blood. Reproduction Fertility and Development 22 684-694. (doi:10.1071/RD09129)

Jeoung M \& Bridges PJ 2011 Cyclic regulation of apoptotic gene expression in the mouse oviduct. Reproduction Fertility and Development 23 638644. (doi:10.1071/RD11011)

Kanaoka Y, Ago H, Inagaki E, Nanayama T, Miyano M, Kikuno R, Fujii Y, Eguchi N, Toh H, Urade $\mathbf{Y}$ et al. 1997 Cloning and crystal structure of hematopoietic prostaglandin D synthase. Cell 90 1085-1095. (doi:10.1016/S0092-8674(00)80374-8)

Kengni JH, St-Louis I, Parent S, Leblanc V, Shooner C \& Asselin E 2007 Regulation of prostaglandin D synthase and prostacyclin synthase in the endometrium of cyclic, pregnant, and pseudopregnant rats and their regulation by sex steroids. Journal of Endocrinology 195 301-311. (doi:10.1677/JOE-07-0353)

Klein C, Bauersachs S, Ulbrich SE, Einspanier R, Meyer HH, Schmidt $S E$, Reichenbach HD, Vermehren $M$, Sinowatz $F$, Blum $H$ et al. 2006 Monozygotic twin model reveals novel embryo-induced transcriptome changes of bovine endometrium in the preattachment period. Biology of Reproduction 74 253-264. (doi:10.1095/biolreprod. 105.046748)

Kobayashi Y, Wakamiya K, Kohka M, Yamamoto Y \& Okuda K 2013 Summer heat stress affects prostaglandin synthesis in the bovine oviduct. Reproduction 146 103-110. (doi:10.1530/REP-12-0479)

Lapointe J \& Bilodeau JF 2003 Antioxidant defenses are modulated in the cow oviduct during the estrous cycle. Biology of Reproduction 68 1157-1164. (doi:10.1095/biolreprod.102.007476)

Lazzari G, Wrenzycki C, Herrmann D, Duchi R, Kruip T, Niemann H \& Galli C 2002 Cellular and molecular deviations in bovine in vitro-produced embryos are related to the large offspring syndrome. Biology of Reproduction 67 767-775. (doi:10.1095/biolreprod. 102.004481)

Leese HJ 1988 The formation and function of oviduct fluid. Journal of Reproduction \& Fertility 82 843-856. (doi:10.1530/jrf.0.0820843)

Li HW, Liao SB, Chiu PC, Tam WW, Ho JC, Ng EH, Ho PC, Yeung WS, Tang F \& O WS 2010 Expression of adrenomedullin in human oviduct, its regulation by the hormonal cycle and contact with spermatozoa, and its effect on ciliary beat frequency of the oviductal epithelium. Journal of Clinical Endocrinology and Metabolism 95 E18-E25. (doi:10.1210/ jc.2010-0273)

Madore E, Harvey N, Parent J, Chapdelaine P, Arosh JA \& Fortier MA 2003 An aldose reductase with 20 alpha-hydroxysteroid dehydrogenase activity is most likely the enzyme responsible for the production of prostaglandin $\mathrm{f} 2$ alpha in the bovine endometrium. Journal of Biological Chemistry 278 11205-11212. (doi:10.1074/jbc. M208318200)
Maillo V, Gaora PO, Forde N, Besenfelder U, Havlicek V, Burns GW, Spencer TE, Gutierrez-Adan A, Lonergan P \& Rizos D 2015 Oviduct-embryo interactions in cattle: two-way traffic or a one-way street? Biology of Reproduction 92 144. (doi:10.1095/biolreprod. 115.127969)

Mammoto A, Masumoto N, Tahara M, Ikebuchi Y, Ohmichi M, Tasaka K \& Miyake A 1996 Reactive oxygen species block sperm-egg fusion via oxidation of sperm sulfhydryl proteins in mice. Biology of Reproduction 55 1063-1068. (doi:10.1095/biolreprod55.5.1063)

Marangos P \& Carroll J 2004 The dynamics of cyclin B1 distribution during meiosis I in mouse oocytes. Reproduction 128 153-162. (doi:10.1530/ rep.1.00192)

Michimata T, Tsuda H, Sakai M, Fujimura M, Nagata K, Nakamura M \& Saito S 2002 Accumulation of CRTH2-positive T-helper 2 and T-cytotoxic 2 cells at implantation sites of human decidua in a prostaglandin D(2)-mediated manner. Molecular Human Reproduction 8 181-187. (doi:10.1093/molehr/8.2.181)

Rekik W, Dufort I \& Sirard MA 2011 Analysis of the gene expression pattern of bovine blastocysts at three stages of development. Molecular Reproduciton and Development 78 226-240. (doi:10.1002/mrd.v78.4)

Rizos D, Ward F, Duffy P, Boland MP \& Lonergan P 2002 Consequences of bovine oocyte maturation, fertilization or early embryo development in vitro versus in vivo: implications for blastocyst yield and blastocyst quality. Molecular Reproduction and Development 61 234-248. (doi:10.1002/(ISSN)1098-2795)

Rizos D, Pintado B, de la Fuente J, Lonergan P \& Gutiérrez-Adán A 2007 Development and pattern of mRNA relative abundance of bovine embryos cultured in the isolated mouse oviduct in organ culture. Molecular Reproduction and Development 74 716-723. (doi:10.1002/ (ISSN)1098-2795)

Rizos D, Ramirez MA, Pintado B, Lonergan P \& Gutierrez-Adan A 2010 Culture of bovine embryos in intermediate host oviducts with emphasis on the isolated mouse oviduct. Theriogenology 73 777-785. (doi:10.1016/j.theriogenology.2009.10.001)

Scaife RM 2004 G2 cell cycle arrest, down-regulation of cyclin B, and induction of mitotic catastrophe by the flavoprotein inhibitor diphenyleneiodonium. Molecular Cancer Therapy 3 1229-1237.

Schmittgen TD \& Livak KJ 2008 Analyzing real-time PCR data by the comparative C(T) method. Nature Protocols 3 1101-1108. (doi:10.1038/ nprot.2008.73)

Smyth GK 2005 Limma:linearmodels for microarray data. In Bioinformatics and Computational Biology Solutions using $R$ and Bioconductor, pp 397-420. New York, NY, USA: Springer. (doi:10.1007/0-387-293620_23)

Song G, Satterfield MC, Kim J, Bazer FW \& Spencer TE 2008 Gastrinreleasing peptide (GRP) in the ovine uterus: regulation by interferon tau and progesterone. Biology of Reproduction 79 376-386. (doi:10.1095/ biolreprod.108.068403)

Surveyor GA, Wilson AK \& Brigstock DR 1998 Localization of connective tissue growth factor during the period of embryo implantation in the mouse. Biology of Reproduction 59 1207-1213. (doi:10.1095/ biolreprod59.5.1207)

Swangchan-Uthai T, Walsh SW, Alexander SL, Cheng Z, Crowe MA, Evans AC \& Wathes DC 2011 Comparison of mRNA for IGFs and their binding proteins in the oviduct during the peri-oestrous period between dairy heifers and lactating cows. Reproduction 142 457-465. (doi:10.1530/REP-11-0154)

Tesfaye D, Lonergan P, Hoelker M, Rings F, Nganvongpanit K, Havlicek V, Besenfelder U, Jennen D, Tholen E \& Schellander K 2007 Suppression of connexin 43 and E-cadherin transcripts in in vitro derived bovine embryos following culture in vitro or in vivo in the homologous bovine oviduct. Molecular Reproduction and Development 74 978-988. (doi:10.1002/(ISSN)1098-2795)

Thompson JG 2000 In vitro culture and embryo metabolism of cattle and sheep embryos - a decade of achievement. Animal Reproduction Science 60-61 263-275. (doi:10.1016/S0378-4320(00)00096-8)

Tremblay K, Vigneault C, McGraw S \& Sirard MA 2005 Expression of cyclin B1 messenger RNA isoforms and initiation of cytoplasmic polyadenylation in the bovine oocyte. Biology of Reproduction 72 1037-1044. (doi:10.1095/biolreprod.104.034793)

Uzumcu M, Homsi MF, Ball DK, Coskun S, Jaroudi K, Hollanders JM \& Brigstock DR 2000 Localization of connective tissue growth factor in 
human uterine tissues. Molecular Human Reproduction 6 1093-1098. (doi:10.1093/molehr/6.12.1093)

Whitley JC, Shulkes A, Salamonsen LA, Vogiagis D, Familari M \& Giraud AS 1998 Temporal expression and cellular localization of a gastrinreleasing peptide-related gene in ovine uterus during the oestrous cycle and pregnancy. Journal of Endocrinology 157 139-148. (doi:10.1677) joe.0.1570139)

Whitley JC, Moore C, Giraud AS \& Shulkes A 2002 Isolation and characterisation of the ovine gastrin-releasing peptide gene; abundant expression in the pregnant uterus and selective expression in fetal tissues. Journal of Endocrinology 175 447-457. (doi:10.1677) joe.0.1750447)

Wirtu G, Pope CE, Damiani P, Miller F, Dresser BL, Short CR, Godke RA \& Bavister BD 2003 Development of in-vitro-derived bovine embryos in protein-free media: effects of amino acids, glucose, pyruvate, lactate, phosphate and osmotic pressure. Reproduction Fertility and Development 15 439-449. (doi:10.1071/RD03090)
Xiao Q, Han X, Challis JR, Hill DJ, Spindel ER, Prasad CJ, Akagi K \& McDonald TJ 1996 Gastrin-releasing peptide-like immunoreactivity is present in human maternal and fetal placental membranes. Journal of Clinical Endocrinology and Metabolism 81 3766-3773. (doi:10.1210/ jcem.81.10.8855836)

Yániz JL, Lopez-Gatius F, Santolaria P \& Mullins KJ 2000 Study of the functional anatomy of bovine oviductal mucosa. Anatomical Record 260 268-278. (doi:10.1002/(ISSN)1097-0185)

Received 11 February 2016

First decision 23 March 2016

Revised manuscript received 5 April 2016

Accepted 8 April 2016 